\title{
FOREIGN EXPERIENCE IN ELECTRONIC TAX ADMINISTRATION AND THE POSSIBILITIES OF ITS USE IN UKRAINE
}

\author{
Nataliia Ortynska ${ }^{1}$, Liudmyla Savranchuk ${ }^{2}$, Svitlana Matchuk ${ }^{3}$
}

\begin{abstract}
The aim of the article is to study the foreign experience of electronic tax administration on the basis of the analysis of scientific literature, and as well as to determine the possibilities for its use with further improvements of domestic legislation in this field in Ukraine. The subject of the study is the foreign experience of electronic tax administration and the possibility of its use in Ukraine. Methodology. The research is based on the dialectical method of scientific knowledge and on general scientific methods, which are based on it, such as: analysis, comparison, analogy, induction, and others. Results of the conducted study have shown that today there is a large number of countries where the digital tax format functions effectively and constantly develop. It is substantiated that the use of the experience provided in the article will give an opportunity to build a simple and effective system of electronic tax administration in Ukraine. And this fact, of course, will influence positively on the financial sphere in Ukraine. Practical impact. The positive experience of establishing a legal framework for the provision of electronic tax administration in foreign countries proves that the digital tax format functions effectively and is constantly developing. Besides, some practices of these countries in the field of electronic tax administration can be rather positive for implementation in the territory of Ukraine. Correlation/originality. Conducting a comparative analysis of the legislation and legal doctrine of Ukraine, and the countries of the European Union and the USA regarding the legal provision of electronic tax administration is the basis for developing the most promising directions of development of domestic legislation in the financial sector of the entire Ukrainian state.
\end{abstract}

Key words: international experience, e-administration, taxes, software, international law.

JEL Classification: H87, K34, K33

\section{Introduction}

An analysis of any innovation legal phenomenon, mechanism, institute, industry, etc., provides for the definition of all its features: specificity, subject structure, subject matter, as well as comparison with a similar category in another legal system. In other words, to form approximately the final result of the implementation and its future prospect, at first you need to see what development it has acquired in another foreign country. In other words, you need to consider international experience. Electronic tax administration is a rather new category in the tax and legal system of Ukraine in general. At the same time, a large number of processes that are just starting in our country, in most developed countries of the West and East have already been existing for a long time. Taking into account all these; we see the need to study the international experience of electronic tax administration and the possibilities of its use in the territory of Ukraine. An analysis of international experience is a necessary condition for any scientific study. The introduction and development of e-administration in this aspect is not an exception.

\footnotetext{
Corresponding author:

${ }^{1}$ Lviv Polytechnic National University, Ukraine.

${ }^{2}$ National Academy of Internal Affairs, Ukraine.

${ }^{3}$ National Academy of Internal Affairs, Ukraine.
}

\section{The state of the research}

Such famous scholars have studied some specific issues concerning the improvement of electronic tax administration in their scientific works as: V. M. Harashchuk, V. M. Shovkovyi, O. M. Lefterova, O.Iu.Dubovyk,Yu.B.Ivanov,A.I.Krysovatyi,A.Ia.Kyzyma, V. V. Karpova, S. V. Klymenko, A. L. Chycherin, Yu. O. Kostenko, A. A. Maievska, T. V. Medynska, R. Iu. Paslavska, A. M. Novytskyi and many others. However, despite alarge number of scientific developments, there is no one comprehensive study devoted to the foreign experience of electronic tax administration in the legal literature. That is why the article aims to study the international experience of electronic tax administration and determine the possibilities for its use in Ukraine.

\section{Presentation of the main material}

During analysing the foreign experience of e-administration and its possible use in national practice, the peculiarities of the use of information technology in the taxation process in the United States of America are 
of considerable interest. It should be noted that the tax system in the USA can be characterized either by national or European wide peculiarities, taking into account the long-term political and territorial dependence of this state on the United Kingdom. As Tkachenko N. M. states, the tax system of the United States consists of three levels corresponding to levels of government, such as: higher (federal level) - the establishment and collection of federal taxes, the administration of which is governed by federal laws, receipts from these taxes are counted to the federal budget; middle level (state level) - the establishment and collection of local taxes, administration of which is regulated by state laws, receipts are counted to state budgets; lower level (lower level of territorial administration - municipalities, districts, etc.) - collection of taxes introduced by local governments, receipts are counted to local budgets (Tkachenko, 2004; Andriushchenko, Hryn, 2015).

The US tax authority is the Internal Revenue Service, which is an organizational member of the Ministry of Finance. The peculiarity of this fiscal service is its dual nature, which results from the implementation of different functions, such as public finance and law enforcement functions (Shalnov, 1993). It should be noted that in accordance with the provisions of the normative legal acts, which are the basis of the activities of this department, the main purpose of the service is to provide US taxpayers with higher quality services. This can be implemented through the assistance in clarifying and enforcing tax liabilities, as well as through applying tax laws in an appropriate and fair manner to all. Thus, the activities of the Internal Revenue Service, first of all, are aimed at the interaction with taxpayers, on partnerships with them (Savchuk, 2013).

The US e-tax administration experience can be called one of the oldest in the world. The introduction of information technology in the tax process was connected with the development of e-government in the United States. Among the many e-government programs in the 1980s, an attempt was made to automate the process of providing tax reporting and also some other tax services. The introduction of e-reporting has become a real breakthrough in this field, which can be proved by the increase in the level of efficiency and volume of taxpayer accounts. It should be noted that software development was made by public entities along with private ones (Sonja E. Pippin, Mehent S. Tosun, 2014).

At the same time, a significant number of troubleshooting moments in electronic reporting were defined. First, e-tax administration has not achieved the same level of development throughout the country, which was due to the lack of opportunities for individuals in some regions to use online tax services. Secondly, the system of electronic tax administration was rather complex compared to other e-government programs, such as online banking. And all these, in fact, had led to situations where payers did not understand how to use it (Sonja E. Pippin, Mehent S. Tosun, 2014). For today, tax reporting can be provided by communication channels in several ways: 1) you can prepare and send tax reporting through an intermediary audit firm; 2) you can fill in the reports by yourself with the help of the purchased software and then send the report through the operator; 3 ) you can fill out the report online on the sites of special operators, a list of which can be found on the portal of the National Revenue Service (Demenko, 2013). The introduction of an electronic tax administration format helped to avoid queues, and also helped to save a large amount of time and money, which people usually spend on reporting to the tax authorities. Besides, the reporting software automatically performs a lot of special calculations and it can find errors, and the electronic key system makes electronic reporting protected from thirdparty intervention (Demenko, 2013).

The next country to study is the UK. We think that its experience can be useful for us. I. O. Tsymbalyuk, O. V. Tsuz and O. V. Kuznetsov state in their studies that Britain is home to the science of taxation. The Scottish economist Adam Smith is the founder of the tax theory, on which the modern British tax system is based. As we all know, he developed the concept of "free trade" and consistently advocated the idea that state intervention in economic processes should be minimal. Smith also criticized indirect taxes, because they lead to wage growth, and consequently, there can be an increase in production costs and a decrease in profits. Instead, he considered rent as the most unproductive expense, which does not turn into self-increasing cost (Kuznetsov, 2010). The Royal Tax and Customs Service of Great Britain is the main body in the administration of taxes on income, profits, capital, the collection and systematization of accounting for customs duties, taxes related to the import of goods, as well as control of import and export flows of goods, etc. The structure of this body consists of four structural divisions, namely: a unit of taxation of individuals, a division of tax accounting, a corporate tax unit, and a unit of tax payment (Shulatova, 2014).

Great Britain also has great experience in electronic tax administration. Particularly, each taxpayer has its own personal electronic tax registration page ("tax account"). All information about a particular taxpayer consolidates. Besides, with the help of an electronic account you can: check and change your address in the taxpayer accounting system; see which tax code is used to calculate the tax; check the state of the pension calculation; manage tax credits, child benefits, etc.; receive emails from tax authorities (Your personal tax account: promotional material, 2017). The approach of organizing information security within the framework of e-tax administration is sufficiently substantiated. For example, information security during working with a personal electronic account of a payer is provided by several factors at once: all online services can be used exclusively by those payers who have registered in the system and have passed the authorization, by entering a personal password and ID; 
a high-quality software is used to protect information; when working with an electronic account, the security of payees information is provided by a special encryption technology called "Secure Sockets Layer" (The free HMRC app: promotional material, 2017). Special mobile applications have been developed and implemented for ease of use of electronic tax administration services in the UK. Using these applications, taxpayer has the opportunity: to review his electronic tax account and determine which taxes are required to be paid; he can review his earnings; check the personal insurance number; review schedule of tax benefits; he can use a special tax calculator; participate in the process of correspondence with the tax authorities, etc. (The free HMRC app: promotional material, 2017).

It should be mentioned that in the United Kingdom, electronic tax administration is developing very quickly since information technology is being introduced in almost all areas of the tax system. First of all, this is due to the convenience of transferring a part of the taxation process to the online format, because its efficiency and effectiveness are significantly increasing under such circumstances. In addition, a significant factor in the rapid development of e-administration is the gaining relevance of e-commerce within the country's financial system. The latter is a wide range of interactive methods for conducting activities on providing consumers with goods and services. Also under the electronic commerce, we can understand any forms of business operations, where the parties interact through electronic technologies, but not in the process of physical exchange or contact (Maievska, 2010). Thus, the transfer of a significant part of the business on the Internet causes the necessity of the formation of a corresponding model of the activities of state bodies. That is why the relevance of electronic tax administration is increasing.

It should be mentioned that e-administration exists and is actively developing not only in the UK and the United States but also in many other foreign countries. For example, in Australia, the general "digitization" of the government's activities became the impetus for the creation of the electronic tax administration system. Special electronic accounts for taxpayers were introduced, as well as convenient conditions for filing tax reporting through the Internet. Besides, in Australia, they pay a lot of attention to the issue of security in the use by taxpayers of special electronic services. Today a special two-tier structure of verification of the identity of the subject of taxation has been introduced, in the process of entering into his own account in the system of electronic administration. In the future, it is planned to introduce another level, which will include confirmation of the taxpayer's voice (Digitalisation of tax: international perspectives).

Brazil has also rather large experience in the field of building electronic tax administration. This state is building a tax system on the principle of complete automation of all processes inside this tax system. Particularly, the key objects of the introduction of innovative technologies were: tax control, taxpayer accounting and tax reporting. At the same time, the introduction of electronic tax administration positively influenced the tax system. Thus, according to $2015,97 \%$ of tax audits were carried out electronically. And in most cases, certain violations of tax laws have been identified (Koval, 2015).

Taking into account all of the above, todayit is necessary to analyse in detail the already existing legal framework in Ukraine, which regulates the administration of taxes. Also, nowadays it is important to introduce effective proposals for changing this base, taking into account the tasks of modernizing the economy on an innovative basis.

\section{Conclusions}

So, the analysis of international experience in the field of electronic tax administration has shown that today there is a large number of countries where the digital tax format functions effectively and is constantly evolving. Besides, the individual developments of these countries in the field of electronic tax administration are positive and necessary for the implementation in the territory of Ukraine. Particularly, in order to improve the e-administration of taxes in our state, it is necessary: - first, we need to involve private organizations in the process of manufacturing software for the system of electronic tax administration. For Ukraine, this experience is extremely useful, because this model of work allows attracting more experienced specialists who can create high-quality and, most importantly, functional software. This, in turn, will significantly improve the efficiency of electronic tax administration in general;

- secondly, in the process of direct introduction and construction of the system of electronic tax administration, it is expedient to use an approach, according to which the key emphasis is not carried out separately on the issue of introduction of technologies in the activities of the authorities. But the main attention is paid to the state support of information infrastructure in general. Mainly, such an approach manifests itself in stimulating the private sector in the implementation of activities related to the creation of new technologies and their implementation in the life of society;

- thirdly, the system of electronic tax administration should be effective, but at the same time, it should be as simple as possible for taxpayers. In this aspect, it is advisable to use a UK experience. In this country, a subject of taxation has access to its electronic account in the system of electronic tax administration from a mobile phone through special software. And the functional and spectrum of electronic services for such an account are quite wide. The use of the mentioned above international experience will make it possible to build a simple and effective system of electronic tax administration in Ukraine, which will surely have a positive impact on the financial industry of the entire state. 


\section{References:}

Tkachenko, N. M. (2004). Podatkovi systemy krain svitu ta Ukrainy. Oblik i zvitnist: navch.-metod. posib. [Tax systems of countries of the world and Ukraine. Accounting and reporting: a teaching manual]. K.: Alerta. (in Ukrainian)

Andriushchenko, I. Ie., Hryn, Yu. V. (2015). Mizhnarodnyi dosvid orhanizatsii podatkovoho administruvannia [International experience in tax administration]. Efektyvna ekonomika, 11. Retrieved from: http://www.economy.nayka.com.ua/ pdf/11 2015/41.pdf (in Ukrainian)

Shalnov, A. (1993). U nalohovoho ynspektora prava polytseiskoho: (SShA) [The tax inspector has the right of the policemen: USA]. Yzvestyia, 17 aprelia. (in Russian)

Savchuk, V. A. (2013). Svitovyi dosvid administruvannia podatkiv [World experience of tax administartion]. Universytetski naukovi zapysky, 2(46), 353-358. (in Ukrainian)

Sonja E. Pippin and Mehent S. Tosun (2014). Electronic Tax Filing in the United States: an Analysis of Possible Success factors. Electronic Journal of e-Government, 12(1), 22-38. (in English)

Demenko, O. Ie. (2013). Zarubizhnyi dosvid administruvannia podatkiv ta mozhlyvosti yoho vykorystannia $\mathrm{v}$ Ukraini [Foreign experience in tax administration and its use in Ukraine]. Nashe pravo, 7, 189-195. (in Ukrainian) Kuznetsov, O. V. (2010). Osoblyvosti suchasnoi brytanskoi podatkovoi systemy [Features of the modern British tax system]. Finansy Ukrainy, 4, 102-113. (in Ukrainian)

Shulatova, Y. S. (2014). Zarubezhnui oput formyrovanyia y orhanyzatsyy edynoho orhana po voprovas fyskalnoi $\mathrm{y}$ tamozhennoi polytyky [Foreign experience in the formation and organization of a single body on fiscal and customs policy]. Vestnyk VHU. Seryia: Pravo, 3, 108-120. (in Russian)

Your personal tax account: promotional material (2017). Retrieved from: https://www.gov.uk/government/ publications/your-personal-tax-account/your-personal-tax-account (in English)

The free HMRC app: promotional material (2017). Retrieved from: https://www.gov.uk/government/ publications/the-official-hmrc-app/the-free-hmrc-app (in English)

Maievska, A. A. (2010). Elektronna komertsiia i pravo: navch.-metod. posibnyk [E-Commerce and Law: a teaching manual]. Kharkiv. (in Ukrainian)

Digitalisation of tax: international perspectives. ICAEW (2016). Retrieved from: https://www.icaew.com/-/ media/corporate/files/technical/digital-tax.ashx (in English)

Koval, O. O. (2015). Poniattia ta systema administruvannia podatkiv ta zboriv v Ukraini [Concept and system of administration of taxes and fees in Ukraine]. Nashe pravo, 1, 159-164. (in Ukrainian) 